\title{
Enhanced positive selection of a transgenic TCR by a restriction element that does not permit negative selection
}

\author{
Pamela S. Ohashl, Rolf M. ZInkernagel', Immanuel Leuscher ${ }^{2}$, \\ Hans Hengartner ${ }^{1}$, and Hanspeter PIrcher ${ }^{1}$ \\ Ontario Cancer Institute, Department of Medical Biophysics, University of Toronto, 500 Sherbourne Street, \\ Toronto, Ontario, Canada M4X 1K9 \\ IInstitute of Experimental Immunology, Department of Pathology, University of Zürich, Schmelzberstrasse \\ 12, 8091 Zürich, Switzerland \\ ${ }^{2}$ Ludwig Institute for Cancer Research, Lausanne Branch, 1066 Epalinges, Switzerland
}

Key words: bm13 bm14, mutant MHC molecules, ontogeny, thymocyte, tolerance

\begin{abstract}
Very llttle is known about the conformational propertles of the MHC molecules that are able to signal positive selection of a given TCR. To try to understand these parameters and to determine whether these requirements are shared with Interactlons during negative selectlon and antigen recognition, we have studled selectlon and antigen recognition of a transgenlc TCR (speciflc for lymphocytlc chorlomeningitls virus glycoproteln and $H-2 D^{b}$ ) In the context of two $D^{b}$ mutants, $\mathrm{H}-2^{\mathrm{bm} 13}$ and $\mathrm{H}-2^{\mathrm{bm} 14}$. The data showed that the transgenlc TCR was not positlvely selected by the H-2 ${ }^{b m 14}$ haplotype but, Interestingly, enhanced positlve selection was seen In ${\mathrm{H}-2^{\mathrm{bm}} 13}$ mice. The transgenic TCR could not be negatively selected in $\mathrm{H}-2^{\mathrm{bm}}{ }^{13}$ animals persistently Infected with the virus (neonatal virus carrler mice), nor could the transgenic TCR be activated by $\mathrm{H}_{-2}{ }^{\text {bm13 }}$ Infected cells in vivo or in vitro. These experiments show that although a TCR may be selected by a mutant MHC molecule, the corresponding viral antigen cannot be recognized in the context of the mutant MHC molecule, as Judged by both negative selection and $\mathrm{T}$ cell reactivity in vivo and In vitro. The 'enhanced' positive selection occurring In the context of $D^{\text {bm13 }}$ suggests that a different conformation of the MHC molecule is able to select the same TCR and also that varlous TCR - ligand aviditles may permit positive selection.
\end{abstract}

\section{Introduction}

The TCR expressed on T lymphocytes is able to transmit signals for three different developmental or functional events: positive selection, tolerance induction, and activation by antigen. The stringent requirements for TCR - ligand interaction have been well characterized for antigen recognition indicating that a defined peptide is presented by a defined MHC molecule with limited variability (for a review see 1 ). In several systems certain amino acid residues of the peptide antigen $(2,3)$ or of the $\mathrm{MHC}$ molecule $(4-7)$ have been shown to be essential for T cell recognition ( 8 and reviewed in 9). In general, TCR recognition of a given peptide presented by a particular MHC is relatively strict.

Several studies have dealt with the interactions that are able to signal negative selection. Studies using superantigens such as Mls and Staphylococcal enterotoxin B (SEB) have shown that a 'gradient' of the clonal deletion may be defined depending on the presenting haplotype $(10-13)$. Using a TCR transgenic model specific for the alloantigen $\mathrm{H}-2 \mathrm{~L}^{\circ}$, Sha et al. (14) have shown that a single amino acid change in the $\mathrm{K}^{\mathrm{b}}$ molecule, which is required for positive selection, resulted in the deletion of T cells. In general, however, it is difficult to judge the flexibility of the interacting ligands during negative selection in classic antigen - MHC-restricted recognition. Recently, Pircher et al. (15) showed that a variant peptide that is able to induce clonal deletion of $T$ cells expressing a transgenic receptor is not able to activate the transgenic $T$ cells. This suggests that antigen recognition by the TCR is demanding higher avidity interactions than tolerance induction.

Other studies have evaluated the TCR - ligand interactions during positive selection and suggest that a peptide may be involved in positive selection (14,16 - 19). Using TCR transgenic mice restricted to $D^{b}$, Jacobs et al. (18) showed that positive selection does not occur in the presence of $D^{\mathrm{bm} 13}$ and $D^{\mathrm{bm} 14}$.

Correspondence to: P. S. Ohashi 
Sha et al. (14) demonstrated that a transgenic $\mathrm{K}^{\mathrm{b}}$-restricted receptor cannot be positively selected in three of the four $\mathrm{K}^{\mathrm{bm}}$ mutants that could be analysed, suggesting that the interaction between the TCR and the selecting complex is relatively rigid.

Based on these experiments, the precise fit, flexibility, and conformational requirements (i.e. the avidity) of a given TCR - MHC-peptide interaction during positive selection, negative selection, and antigen activation is difficult to define at present. Therefore a lymphocytic choriomeningitis virus (LCMV)$D^{b}$-specific transgenic TCR for positive and negative selection in vivo, as well as for antigen recognition in vivo and in vitro, in mice expressing mutant $D^{b}$ molecules has been evaluated.

\section{Methods}

\section{Animals}

Inbred mice were purchased from the Institut für Zuchthygiene, Tierspital, University of Zurich, Switzerland. B6.C-H-2 $2^{\mathrm{bm} 13}$ $\left(\mathrm{H}-2^{\mathrm{bm} 13}\right)$ and B.6C-H-2 $2^{\mathrm{bm} 14}\left(\mathrm{H}-2^{\mathrm{bm} 14}\right)$ animals $(20,21)$ were kindly provided by Dr Cornelis J. Melief. The TCR transgenic mouse line $327(22)$ was crossed into the $\mathrm{H}-2^{\mathrm{bm} 13}$ and $\mathrm{H}-2^{\mathrm{bm} 14}$ strains using the following strategy. TCR transgenic $\mathrm{H}-2^{\text {bid }}$ animals were developed by mating the TCR transgenic $H \cdot 2^{\text {bho }}$ animals with $B A L B / c$ mice $\left(H-2^{2 / / \sigma}\right)$. It has been previously demonstrated that this transgenic TCR could not be positively selected in a predominantly BALB/c background (23). TCR transgenic positive $\mathrm{H}-2^{\mathrm{b} / \mathrm{d}}$ animals were then bred with homozygous $\mathrm{H}-2^{\mathrm{bm} 13}$ or $\mathrm{H}-2^{\mathrm{bm} 14}$ animals. Offspring from these breeding pairs were either $\mathrm{H}-2^{\mathrm{b} / \mathrm{bm}}$ or $\mathrm{H}-2^{\mathrm{d} / \mathrm{bm}}$ that were positive or negative for the transgene. The $\mathrm{MHC}$ haplotype was determined by staining peripheral blood lymphocytes with an $H-2^{\mathrm{d}}$-specific antibody (24).

\section{Flow cytometry analysis}

Cells $\left(1 \times 10^{6}\right)$ were incubated with various mAbs in $100 \mu$ volume balanced salt solution (BSS); $2 \%$ fetal calf serum (FCS); $0.1 \%$ sodium azide for $30 \mathrm{~min}$ at $4^{\circ} \mathrm{C}$. The cells were washed and incubated with fluoresceinated antibodies. Analysis of blood lymphocytes was performed after lysis of red blood cells. Viable cells $(10,000)$ were analysed on an EPICS profile analyser for single parameter analysis and 20,000 viable cells were analysed in 2-3-colour histograms. The mAbs used were KT3 (rat antiCD3; 25), KJ16 (rat anti- $V_{\beta} 8.1,8.2 ; 26$ ), B20.1 (rat anti- $V_{\alpha} 2 ; 27$ ), and anti-CD4 conjugated with phycoerythrin (PE) (BectonDickinson, Belgium), FITC conjugated anti-CD8 (BectonDickinson). For 3-colour analysis, biotinylated anti-CD8 was used together with streptavidin-RED613 (Gibco BRL, Basel, Switzerland). The percentages given for 2-colour analysis were obtained by defining quadrants based on the staining of thymocytes from negative littermate controls. The figures have been cropped to show the relevant data.

\section{Cytotoxic assays}

Animals were primed with 200 p.f.u. of the WE strain of LCMV (obtained from Dr F. Lehmann-Grube, Hamburg, Germany). Eight days later the spleen was removed and the effector cells were incubated, together with target cells, at a ratio of $70: 1,23: 1$, $8: 1$, and $3: 1$. Target cells were either fibroblast lines MC57G $\left(K^{b} D^{b}\right), B 10 . A(5 R)\left(K^{b} D^{d}\right)$, or B10.HTG $\left(K^{d} D^{b}\right)$, or concanavalin $A$ (Con $A$ ) induced spleen cell blasts. The blast cells were prepared by culturing spleen cells with $3 \mu \mathrm{g} / \mathrm{ml}$ Con A (Pharmacia, Uppsala, Sweden) for $48 \mathrm{~h}$ and purification over Ficoll gradients. Targets were incubated with ${ }^{51} \mathrm{Cr}$, with or without peptides, for $2 \mathrm{~h}$. The peptide antigen used in these experiments was IKAVYNFATCG. The effector cells were incubated with target cells for $4-5 \mathrm{~h}$ and the supernatant was removed and counted. Per cent specific release was calculated as described previously (28).

\section{Proliferation assays}

Lymph node cells $\left(1 \times 10^{5}\right)$ from TCR transgenic $\mathrm{H}-2^{\text {b }}$ mice and from negative littermate controls were incubated with $2 \times 10^{4}$ LCMV-infected macrophages or uninfected macrophages from $\mathrm{H}-2^{b}$ and $\mathrm{H}-2^{\mathrm{bm} 13}$ mice. Stimulator macrophages were irradiated with 2000 rad. After $48 \mathrm{~h}\left[{ }^{3} \mathrm{H}\right]$ thymidine was added overnight. The wells were harvested and incorporated radioactivity was counted. Data show the average counts from triplicate samples.

\section{Generation of virus carrier animals}

Newborn mice from $\left(\mathrm{H}-2^{d}\right.$ transgenic $\left.\times \mathrm{H}-2^{\mathrm{bm}}\right) \mathrm{F}_{1}$ or control $\mathrm{H}-2^{\mathrm{b}}$ transgenic mice were injected with $3 \times 10^{5}$ p.f.u. of LCMV i.p. Mice (3- to 4-week-old) were sacrificed and thymocytes were analysed by flow cytometry. Mice were confirmed to be virus carriers by injection of $30 \mu$ of their blood into the footpad of mice. Footpad swelling was seen $8-9$ days after challenge with the blood, indicating that the virus could be transferred from the carrier animals.

\section{Results}

$H-2 D^{b}$ is required for positive selection of the transgenic TCR

TCR transgenic mice have been generated from a cytotoxic $T$ cell clone specific for the LCMV glycoprotein (GP) (amino acids $32-42$ ) presented in the context of $D^{b}(22)$. To formally demonstrate that the TCR transgenic receptor requires the $D^{b}$ molecule for positive selection, $\mathrm{H}-2^{d}$ TCR transgenic mice were bred with B10.HTG (Kd $\left.\mathrm{K}^{\mathrm{b}}\right)$ and $\mathrm{B} 10 . \mathrm{A}(5 \mathrm{R})\left(\mathrm{K}^{\mathrm{b}} \mathrm{D}^{\mathrm{d}}\right)$ mice. Positive selection of class I restricted transgenic TCRs has previously been characterized by a skewing of thymocytes to the CD8 lineage $(22,29,30)$. Thymocytes from TCR transgenic B10.HTG and B10.A(5R) animals were stained with CD4 and CD8 and compared with TCR transgenic animals in the selecting $\mathrm{H}-2^{\mathrm{b}}$ $\left(19.0 \% \mathrm{CD}^{+} \pm 2.4, n=7\right)$ and non-solecting $\mathrm{H}-2^{\mathrm{d}}$ background $\left(6.0 \% \mathrm{CDB}^{+} \pm 1.4, n=4\right)$ (Fig. 1). Prominent skewing to the CD8 lineage was seen only in the presence of $D^{b}(24.5 \%$ $\mathrm{CD}^{+} \pm 0.7, n=2$ ). Further analysis has shown that the transgenic $\alpha$ and $\beta$ TCR are present at high levels on $\mathrm{CD}^{+}$ cells only in animals expressing $\mathrm{H} \cdot 2^{\mathrm{b}}$ and not $\mathrm{H} \cdot 2^{\mathrm{d}}(31,32)$. Taken together, these data show that positive selection of the transgenic TCR occurs only in the presence of $\mathrm{D}^{\mathrm{b}}$.

The effects of changes in the groove of the MHC or TCR - MHC interaction during positive selection, negative selection, and antigen recognition was examined using two $D^{\mathrm{b}}$ mutant mouse strains called B6.C-H-2 $2^{\mathrm{bm} 13}\left(\mathrm{H}-2^{\mathrm{bm} 13} ; \mathrm{K}^{\mathrm{b}} \mathrm{D}^{\mathrm{bm} 13}\right)$ and B6.C-H. $2^{\mathrm{bm} 14}$ $\left(H-2^{\mathrm{bm} 14} ; \mathrm{K}^{\mathrm{b}} \mathrm{D}^{\mathrm{bm} 14}\right)(20) . H \cdot 2^{\mathrm{tm} 13}$ has three amino acid substitutions on the $\beta$-pleated sheet of the $D^{\text {b }}$ class I molecule (residues 114 Leu - Glu, 116 Phe-Tyr, 119 Glu - Asp), while H-2 ${ }^{\text {bm14 }}$ has a single amino acid change on the $\alpha$-helix of $D^{b}$ (residue 70 Glu - Asp) (21). These alterations of the $D^{\mathrm{b}}$ molecule result in 


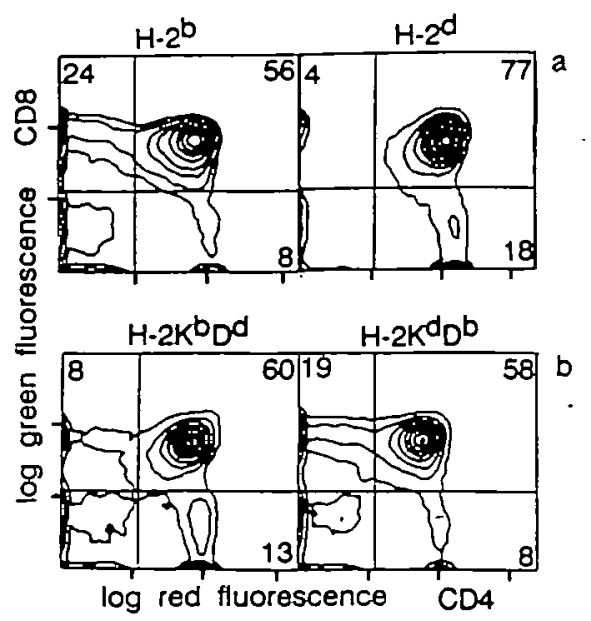

Fig. 1. Positive selection of the transgenic TCR by $D^{b}$. Thymocytes from TCR transgènic mice $\left(K^{d} D^{d}\right.$, BALB/c origin) bred with C57BL/6 $\left(K^{b} D^{b}\right)$, $B 10 . A(5 R)\left(K^{b} D^{d}\right)$, and $\left.B 10 . H T G\left(K^{d} D^{b}\right)\right]$ were analysed using mAbs specific for CD4 and CD8. At least two animals were analysed in each haplotype and a representative analysis is shown. The following percentages were obtained. $\mathrm{K}^{\mathrm{b}} \mathrm{D}^{\mathrm{b}}$ : $19.0 \% \mathrm{CD}^{+} \pm 2.4,63 \%$ $\mathrm{CD}^{+}{ }^{+} \mathrm{CD}^{+} \pm 6.6, \quad 4.6 \% \quad \mathrm{CD}^{+} \pm 2.5, \quad n=7 ; \quad \mathrm{K}^{\mathrm{d}} \mathrm{D}^{\mathrm{d}}: \quad 6.0 \%$ $\mathrm{CD}^{+} \pm 1.4,69.0 \% \mathrm{CD}^{+} \mathrm{CD}^{+} \pm 10.9,15.89 \% \mathrm{CD}^{+} \pm 5.5, n=4$;

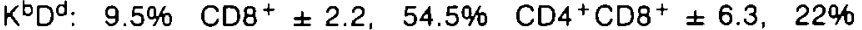
$\mathrm{CD}^{+} \pm 5.6, \quad n=2 ; \quad \mathrm{K}^{\mathrm{d}} \mathrm{D}^{\mathrm{b}}, \quad 24.5 \% \mathrm{CDB}^{+} \pm 0.7, \quad 56.0 \%$ $\mathrm{CD}^{+}{ }^{+} \mathrm{CD}^{+}+0.0,8 \% \mathrm{CD}^{+} \pm 0.0, n=2$.

changes that have been predicted to alter the peptide binding pocket, as determined by computer modelling (33).

\section{$H-2 D^{\text {bm13 }}$ permits positive selection of the transgenic TCR}

Positive selection of the transgenic TCR was studied in $\mathrm{H}-2^{\mathrm{bm} 13}$ and $\mathrm{H}-2^{\mathrm{bm} 14}$ mice using two criteria: a skewing to $\mathrm{CD}^{+}$ thymocytes $(22,29,30)$ and the presence of a subpopulation of thymocytes expressing $\mathrm{CD} 3$ at intermediate levels which has been previously correlated with positive selection $(23,34,35)$. Because positive selection of the transgenic TCR does not occur in $\mathrm{H}-2^{d}$ mice, $\mathrm{H}-2^{\mathrm{d} / \mathrm{bm}}$ mice were examined for the positive selection of the transgenic TCR. TCR transgene positive $\mathrm{H}-2^{\mathrm{b} / \mathrm{bm}}$ mice were examined as controls to ensure that the $D^{\mathrm{bm}}$ alleles did not negatively affect maturation of the TCR transgene positive thymocytes. Thymocytes stained with CD4 and CD8 revealed skewing of the transgenic TCR towards $\mathrm{CD} 8^{+}$thymocytes in $\mathrm{H}-2^{\mathrm{dhom} 13}$ mice $\left(32.0 \% \mathrm{CD}^{+} \pm 3.4 \%, n=6\right)$ but not $\mathrm{H}-2^{\mathrm{d} / \mathrm{mm} 14}$ mice $\left(7.8 \% \mathrm{CD}^{+} \pm 1.0 \%, n=4\right)$ (Fig. $2 \mathrm{~A}$ and $\left.\mathrm{C}\right)$. An unusual population of $\mathrm{CD} 4{ }^{+} \mathrm{CD} 8^{\mathrm{b}}$ cells was often seen in $\mathrm{H}-2^{\mathrm{d} / \mathrm{om} 13}$ mice, but how they fit into $T$ cell ontogeny in these animals is not known. CD3 single parameter analysis of thymocytes showed the presence of TCR CD3 ${ }^{\text {int }}$ peaks in mice carrying the $\mathrm{H}-2^{\mathrm{b}}$ allele or in $\mathrm{H}-2^{\mathrm{d} / \mathrm{hm} 13}$, but not the $\mathrm{H}-2^{\mathrm{d} / \mathrm{bm} 14}$ TCR transgenic mice (Fig. $2 \mathrm{~B}$ and $\mathrm{D}$ ). Comparable results are also seen when the transgenic $V_{\alpha}$ or $V_{\beta}$-specific antibodies were used for analysis (data not shown). These results indicated that positive selection occurred in $\mathrm{H}-2^{\mathrm{bm} 13}$, but not $\mathrm{H}-2^{\mathrm{bm} 14}$, mice.

\section{Enhanced positive selection by $\mathrm{H} \cdot 2^{\mathrm{bm} 13}$}

Interestingly examination of positive selection of the transgenic TCR by $D^{\text {bm } 13}$ compared with $D^{\mathrm{b}}$ consistently showed a more
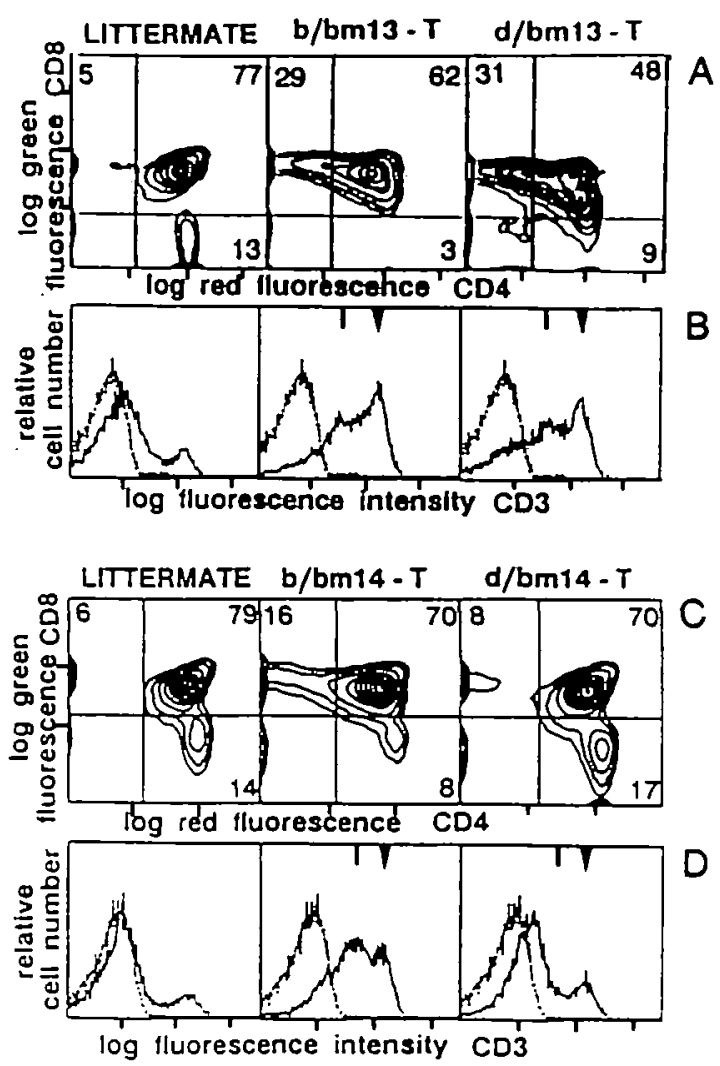

Fig. 2. Positive selection of the transgenic TCR by $\mathrm{H}-2^{\mathrm{bm} 13}$ but not $\mathrm{H}-2^{\mathrm{bm} 14}$. Thymocytes from $\mathrm{H} \cdot 2^{\mathrm{b} / \mathrm{bm}}$ and $\mathrm{H}-2^{\mathrm{d} / \mathrm{hm}}$ transgenic mice, es well as nontransgenic littermate controls, were analysed in the $\mathrm{H} \cdot 2^{\mathrm{bm} 13}$ (A and $B$ ) and $\mathrm{H}-2^{\text {bm14 }}(C$ and $D)$ mutant phenotypes using mAbs specific for CD4, CD8 and CD3 (KT3) (25). (B and D) Broken lines represent celts stained with the second stage antibody alone. The vertical bar at the top of the profiles indicates the TCR - CD3 intermediate population and the triangle indicates TCR $-\mathrm{CD}^{\text {hi }}$ cells. Four to six animals of each type were analysed and a representative analysis is shown. The following percentages were obtained. $\mathrm{K}^{\mathrm{b}} \mathrm{D}^{\mathrm{bm} 13}$ : $32.0 \% \mathrm{CD}^{+} \pm 3.4,44.3 \%$ $\mathrm{CD}^{+}{ }^{+} \mathrm{CD} 8^{+} \pm 10.7,13.9 \% \mathrm{CD}^{+} \pm 7.5, n=6 ; \mathrm{K}^{\mathrm{b}} \mathrm{D}^{\mathrm{bm} 14}: 7.8 \%$ $\mathrm{CD} 8^{+} \pm 1.0,60.7 \% \mathrm{CD} 4^{+} \mathrm{CD} 8^{+} \pm 10.1,14.2 \% \mathrm{CD}^{+} \pm 7.8, n=4$.

prominent skewing to the $\mathrm{CD}^{+}$thymocyte population (Fig. 3A). In $D^{\mathrm{b}}$ animals the $\mathrm{CD} 8^{+}$population in the thymus is $19.0 \%$ $( \pm 2.4 \%, n=7)$. The CD8 ${ }^{+}$thymocyte population in $D^{\mathrm{bm} 13}$ animals is $-34.0 \%( \pm 3.4 \%, n=6)$. In addition, an increased

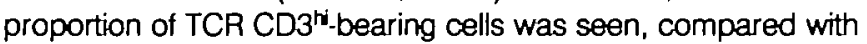
the number of $T$ cells expressing the TCR CD3 at intermediate densities (Fig. 3B). Examination of TCR transgenic thymocytes in the presence of $D^{b}$ and $D^{\mathrm{bm} 13}$ by 3-colour cytofluorometric analysis was also performed to study the TCR CD3 levels during the progression from double positive thymocytes to $\mathrm{CD}^{+}$ thymocytes. In the $\mathrm{CD}^{+}$thymocytes, a high level of $\mathrm{CD} 3$ expression was seen, as expected in a mature subpopulation of $T$ cells in both the $D^{b}$ and $D^{\text {bm13 }}$ transgenic animals (Fig. 4a). The $C D 4^{1 \%} / C D 8^{+}$subset contained a majority of $C D 3^{\text {int }}$ in the $D^{b}$ transgenic animals, compared with the predominant $C D 3^{\text {hi }}$ cells in the $\mathrm{D}^{\mathrm{bm13}}$ mice (Fig. 4b). The $\mathrm{CD} 4{ }^{+} \mathrm{CD} 8^{+}$population contained very few $C D 3^{\text {ti }}$ cells in $D^{\mathrm{b}}$ mice, while the $D^{\mathrm{bm} 13}$ double positive thymocytes had considerably more $C D 3^{\text {hi }}$ cells 

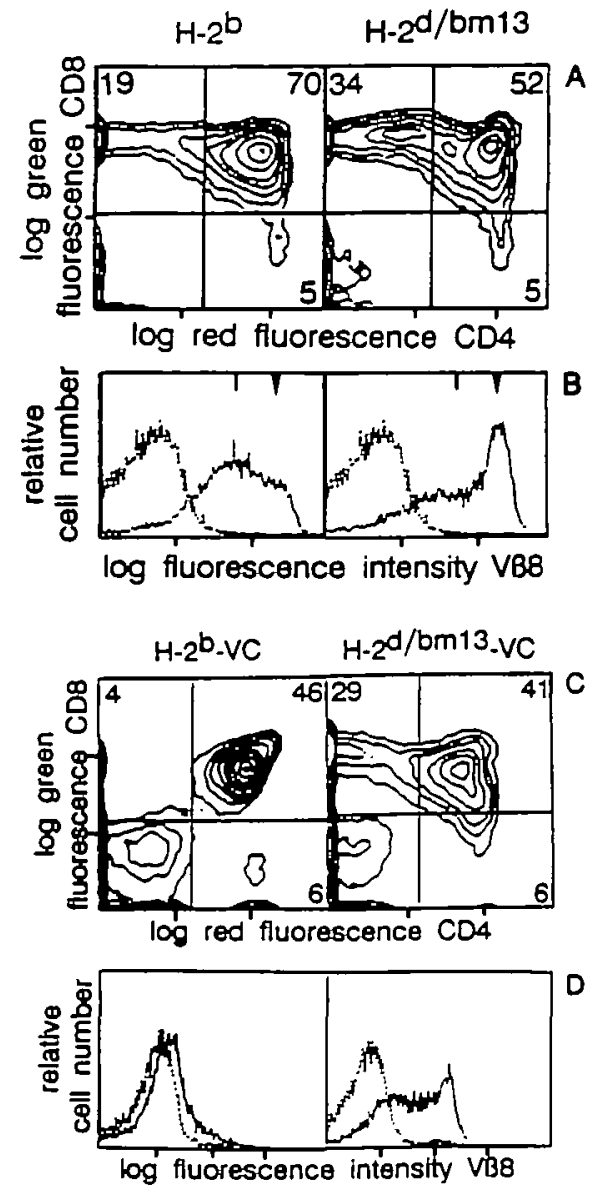

Flg. 3. Positive and negative selection of the transgenic TCR in mice carrying the $\mathrm{H}-2^{\mathrm{bm} 13}$ alleles. (A) Thymocytes from $\mathrm{H}-2^{\mathrm{b}}$ TCR transgenic mice of TCR transgenic $\mathrm{H}-2^{\mathrm{d} h \mathrm{~m}} 13$ mice were compared using $\mathrm{CD} 4$ and $\mathrm{CD} 8(\mathrm{~B})$ or $\mathrm{KJ} 16$ that reacts with the transgenic receptor $\mathrm{V}_{8} 8.1$ (26). (C and D) Clonal deletion of the transgenic TCR was examined in $\mathrm{H}-2^{b}$ and $\mathrm{H}-2^{\mathrm{bm} 13}$ virus carrier mice. (C) Thymocytes from 3- to 4-week-otd mice were analysed with CD4 and CD8 or (D) KJ 16 mAbs. Profiles for (B) and (D) are as described in Fig. 2. A representative animal chosen from the three analysed is shown in the figure.

(Fig. 4c). This suggested that the transgenic TCR may be more efficiently selected to express TCR CD3 at high levels in the $\mathrm{H}-2^{\mathrm{bm} 13}$ haplotype.

To examine whether efficient selection resulted in an increase of peripheral T cells, the number of T lymphocytes in the blood and lymph nodes was investigated. The peripheral blood lymphocytes from TCR transgenic $\mathrm{H}-2^{\mathrm{bm} 13}$ mice had an increased number of T cells (52 $\pm 4 \%, n=8)$ compared with transgene negative littermate controls $(31 \pm 2 \%, n=8)$ or TCR transgenic $\mathrm{H}-2^{\mathrm{b}}$ mice $(36 \pm 4 \%, n=8$ ) (Table 1). Lymph nodes also contained elevated levels of $T$ cells, with a predominant skewing to $\mathrm{CD}^{+}$cells in both $\mathrm{D}^{\mathrm{b}}$ and $\mathrm{D}^{\mathrm{bm} 13}$ transgenic animals (Table 1). Transgenic $\mathrm{H}-2^{\mathrm{brm} 13}$ mice, ranging in age from 20 days to 6 months; show similar distributions of CD3, CD4, and CD8 positive cells. Analysis of the expression of the transgenic TCR on CD8 + lymph node cells was also performed (Fig. 5). Two-colour anlaysis, using either B20.1 $\left(V_{\alpha} 2\right)$ and $\mathrm{CD} 8$ or $\mathrm{KJ} 16(\mathrm{~N} 8)$ and $\mathrm{CD} 8$, indicate that virtually all $\mathrm{CD} 8^{+}$

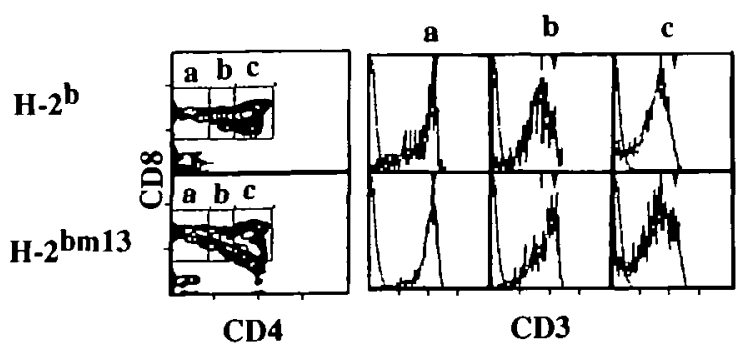

Flg. 4. Comparison of TCR-CD3 expression from double positive to single CD8 positive thymocytes in $\mathrm{H} \cdot 2^{\mathrm{b}}$ and $\mathrm{H}-2^{\mathrm{bm} 13}$ transgenic mice. Thymocytes from $\mathrm{H}-2^{\mathrm{b}}$ and $\mathrm{H}-2^{\mathrm{bm} 13}$ were triple stained with $\mathrm{CD} 3, \mathrm{CD} 4$, and CD8 antibodies. The CD4CD8 profile is shown (left), and parts $a_{\text {, }}$ $b$, and $c$ (right) show the levets of $\mathrm{CD} 3$ on thymocytes expressing different levels of CD4 and CD8, as shown in the corresponding boxed arees $a$, $b$, and c. (a) $\mathrm{CD} 3$ expression on $\mathrm{CD}^{+}$thymocytes; (b) $\mathrm{CD} 3$ expression on $\mathrm{CD} 4^{\circ} \mathrm{CD} 8^{+}$thymocytes; and (c) $\mathrm{CD} 3$ expression on $\mathrm{CD} 4^{+} \mathrm{CD} 8^{+}$ thymocytes. The vertical bar indicates thymocytes expressing TCR - CD3 at intermediate levels and the triangle indicates TCR - CD3 high levels. It should be noted that in these animals CD3 expression parallets the expression of the transgenic TCR as assessed by staining with $\mathrm{KJ} 16$ and B20.1 V region-specific antibodies (23 and data not shown). Two animals have been examined and similar results were obtained.

Table 1. Analysis of T cells in the blood and lymph node

\begin{tabular}{|c|c|c|c|c|c|}
\hline \multirow[t]{2}{*}{ Mice } & & \multicolumn{2}{|l|}{ Blood } & \multicolumn{2}{|c|}{ Lymph node celts } \\
\hline & & $\%$ CD3 & $96 \mathrm{CD} 3$ & $9 \mathrm{CD} 4$ & $96 \mathrm{CD} 8$ \\
\hline $\mathrm{H} \cdot 2^{\mathrm{b}}$ & $\begin{array}{l}\operatorname{tg}^{-} \\
\operatorname{tg}^{+}\end{array}$ & $\begin{array}{l}32 \pm 5 \\
36 \pm 4\end{array}$ & $\begin{array}{l}55 \pm 4 \\
59 \pm 4\end{array}$ & $\begin{array}{l}38 \pm 1 \\
11 \pm 2\end{array}$ & $\begin{array}{l}18 \pm 3 \\
57 \pm 7\end{array}$ \\
\hline $\mathrm{H}-2^{\operatorname{bm} 13}$ & $\begin{array}{l}\operatorname{tg}^{-} \\
\operatorname{tg}^{+}\end{array}$ & $\begin{array}{l}31 \pm 2 \\
52 \pm 4\end{array}$ & $\begin{array}{l}55 \pm 3 \\
68 \pm 5\end{array}$ & $\begin{aligned} 39 & \pm 2 \\
7 & \pm 1\end{aligned}$ & $\begin{array}{l}19 \pm 5 \\
69 \pm 5\end{array}$ \\
\hline
\end{tabular}

cells express the transgenic $V_{\alpha}$ and $V_{\beta}$. Taken together these data suggest that $D^{\mathrm{bm} 13}$ was able to more efficiently select the transgenic TCR compared with the original $D^{b}$ molecule. It is possible that the increase in T cells is also caused by peripheral expansion of $\mathrm{T}$ cells expressing the transgenic receptor.

Clonal deletion of the transgenic TCR does not occur in $\mathrm{H} \cdot 2^{\mathrm{bm} 13}$ mice neonatally infected with LCMV

Negative selection of LCMV-specific transgenic T cells was examined in transgenic $\mathrm{H}-2^{\mathrm{bm} 13}$ animals. Previous experiments have shown that injection of newborn TCR transgenic mice with LCMV results in tolerance to the virus by clonal deletion of the $\mathrm{CD}^{+}{ }^{+} \mathrm{CD} 8^{+}$double positive TCR transgenic cells in $\mathrm{H}-2^{\mathrm{b}}$ mice (22), but not $\mathrm{H}-2^{d}$ mice (data not shown). To determine if clonal deletion of the transgenic TCR also occurs in $\mathrm{H}-2^{\mathrm{bm} 13}, \mathrm{H}-2^{\text {d }}$ TCR transgenic mice were bred with $\mathrm{H}-2^{\mathrm{bm} 13}$ mice and offspring were neonatally infected with LCMV. Thymocytes were examined by 2 -colour cytofluorometry at $3-4$ weeks of age using anti-CD4, anti-CD8, and $V_{A}$-specific mAbs. Thymocytes from $\mathrm{H}-2^{\mathrm{d} / \mathrm{om} 13}$ TCR transgenic carrier mice showed a skewing to the CD8 ${ }^{+}$ mature subset (Fig. 3C). Analysis with $\mathrm{V}_{\beta} 8$-specific antibodies showed that the transgenic TCR was expressed on the majority of $\mathrm{H}-2^{\mathrm{d} / \mathrm{m} m 13}$ thymocytes at intermediate and high levels, 


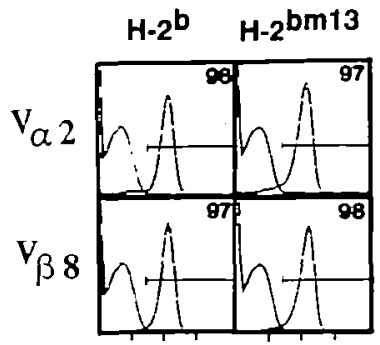

$\log$ fluorescence

Fig. 5. Transgenic TCR expression on CD8 $8^{+}$lymph node cells. Lymph nodes cells from TCR transgenic $\mathrm{H}-2^{\mathrm{b}}$ and $\mathrm{H}-2^{\mathrm{bm} 13}$ animals were stained with B20.1 and CD8 or $K J 16$ and CD8. The $V_{\alpha} 2$ expression (B20.1) or $V_{\beta} 8$ expression $(K J 16)$ on $C D 8^{+} T$ cells is shown in the figure. This figure is representative of three animals.

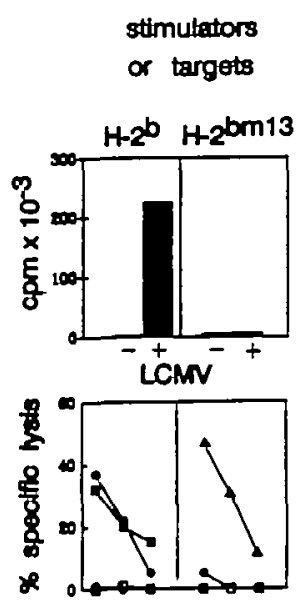

Flg. 6. Transgenic TCR does not recognize LCMV presented in the context of $\mathrm{H}-2^{\mathrm{bm} 13}$. Proliferation assays (top panel) using unprimed transgenic lymph node cells and either infected $(+)$ or uninfected $(-)$ macrophages from $\mathrm{H}-2^{b}$ or $\mathrm{H}-2^{\mathrm{bm} 13}$ animals were performed. For lower values the SEM was between 30 and 50 c.p.m., while the positive response had an SEM of $10.4 \times 10^{-3}$. Lymph node cells from transgene negative littermates were used as negative controls. The thymidine incorporation from these wells ranged from 300 to 600 c.p.m. (not shown in this figure). This figure is representative of four animals. Cytotoxicity assays (bottom panel) using effector spleen cells from $\mathrm{H}-2^{\text {b }}$ TCR transgenic mice $(\bullet), \mathrm{H}-2^{\mathrm{bm} 13}(\mathbf{\Delta})$, or C57BL/6 mice (U) primed with LCMV. Spleen cell blasts from the $\mathrm{H}-2^{\mathrm{b}}$ or $\mathrm{H}-2^{\mathrm{bm} 13}$ mice were used as target cells and labelled with ${ }^{51} \mathrm{Cr}$ with $(\bullet, \square)$ or without $(O, \square)$ the GP peptide $(32-42)$. Effector to target ratios began at $70: 1$, with 3 -fold dilutions.

suggesting that clonal deletion did not occur in $\mathrm{H}-2^{\mathrm{bm} 13}$ transgenic carrier mice (Fig. 3D). Also, 80-90\% of peripheral $\mathrm{CD8}^{+} \mathrm{T}$ cells were found to express both transgenic $V_{\alpha}$ and $V_{s}$ receptors (data not shown). This suggests that either LCMV determinants presented together with $\mathrm{H} \cdot 2^{\mathrm{bm} 13}$ were not recognized by the transgenic TCR thymocytes and/or that the glycoprotein peptide is not efficiently presented by $D^{\mathrm{bm} 13}$ in vivo.
Transgenic $T$ cells are not activated by LCMV-infected $D^{b m 13}$ cells

Experiments were performed to see whether mature peripheral transgenic TCR could recognize LCMV-infected $\mathrm{H}-2^{\operatorname{tm} 13}$ cells. When $T$ cell competent mice are infected intracerebrally with LCMV, they succumb to a CD8 T cell mediated immunopathological disease. However, if mice cannot mount a strong antiviral cytotoxic T lymphocyte (CTL) response at the optimal time after infection, the mice may survive $(36-38)$. To determine whether antigen recognition occurs in vivo, TCR transgenic $\mathrm{H} \cdot 2^{2 \mathrm{dbm} 13}$ and $\mathrm{H}-2^{\mathrm{b} / \mathrm{bm}+3}$ mice were injected intracerebrally with $2 \times 10^{6}$ p.f.u. of LCMV. The majority of transgenic mice that expressed the $\mathrm{H}-2^{\mathrm{b}}$ allele died within $3-7$ days $(5 / 6,4 \pm 1.7)$, while none of the $\mathrm{H}-2^{\mathrm{d} / \mathrm{mm} 13}(\mathrm{O} / 4)$ transgenic animals died. This indicated that the transgenic TCR cannot efficiently recognize LCMV-infected $\mathrm{H}-2^{\mathrm{bm} 1}$ cells in vivo.

The ability of the transgenic receptor to recognize LCMVinfected or peptide-coated $\mathrm{H}-2^{\text {brm13 }}$ cells was also evaluated by two in vitro assays. Proliferation assays were performed by culturing TCR transgene positive lymph node cells $\left(\mathrm{H}-2^{b}\right)$ with uninfected or LCMV-infected macrophages isolated from $\mathrm{H}-2^{\mathrm{b}}$ or $\mathrm{H}-2^{\mathrm{bm} 13}$ mice. Lymph node cells from non-transgenic littermates were used as negative control cells. Proliferation measured by thymidine uptake was seen only when transgenic lymph node cells were stimulated with LCMV-infected $\mathrm{H}-2^{\mathrm{b}}$ macrophages (Fig. 6), but not infected $\mathrm{H}-2^{\mathrm{bm} 13}$ macrophages. CTL assays, using effector cell populations from TCR transgenic mice, C57BL/6, and $\mathrm{H}-2^{\mathrm{bm} 13}$ mice primed with LCMV, were tested on $\mathrm{H}-2^{\mathrm{b}}$ or $\mathrm{H}-2^{\mathrm{bm} 13}$ target cells that were either preincubated for $2 \mathrm{~h}$ with or without the peptide GP(32-42). Figure 6 indicates that transgenic effector cells could only recognize target cells expressing the GP peptide plus $\mathrm{H}-2^{b}$, and not the peptide presented in the context of $\mathrm{H}-2^{\mathrm{bm} 13}$. Taken together, these experiments demonstrate that the transgenic TCR cannot recognize LCMV-infected $\mathrm{H}-2^{\mathrm{bm} 13}$ cells.

\section{$\mathrm{H}-2^{\mathrm{bm} 13}$ and peptide GP(32-42) presentation}

Results from the CTL assay showed that $\mathrm{H}-2^{\mathrm{bm} 13}$ mice $\left(K^{\mathrm{b}} D^{\mathrm{bm} 13}\right)$ could generate a CTL response specific for the peptide $\mathrm{GP}(32-42)$. To determine whether the cytotoxic response was mediated by peptide $\mathrm{GP}(32-42)$ binding to $\mathrm{K}^{\mathrm{b}}$ or $\mathrm{D}^{\mathrm{bm} 13}$, the following assays were performed, based on the assumption that $D^{b}$-restricted effector $T$ cells would cross react with the GP peptide presented on $D^{\mathrm{km} 13}$ and vice versa. Cross reactivity of $D^{b}$-restricted clones on $D^{b}$ mutants expressing the appropriate antigen has been previously demonstrated $(4,5)$, and therefore an in vivo polyclonal response could possibly generate a cross reactivity $D^{b}$ - or $D^{b m 13}$-restricted response (as shown for the $K^{b}$ mutants; 7). Effector cells from C57BL/6 (Kb $\left.D^{\mathrm{b}}\right), B 10 . A(5 R)$ $\left(K^{b} D^{d}\right), 810 . A(4 R)\left(K^{k} D^{b}\right)$, and $H-2^{b m 13}\left(K^{b} D^{b m 13}\right)$ mice primed with LCMV were tested on a variety of target cells that were incubated with or without the peptide $\mathrm{GP}(32-42)$. Results suggest that $D^{\mathrm{tm} 13}$ does not present GP(32-42) efficiently because LCMV-infected $\mathrm{H}-2^{\mathrm{bm} 13}$ mice did not generate effector cells that can recognize the peptide on B10.HTG (Kd $\left.\mathrm{K}^{\mathrm{d}}\right)$ target cells bearing the relevant $D^{b}$ molecule (Table 2). In the corollary assay, $B 10 . A(4 R)\left(K^{k} D^{b}\right)$ effector cells did not recognize peptidecoated $\mathrm{H} \cdot 2^{\mathrm{bm} 13}\left(\mathrm{~K}^{\mathrm{b}} \mathrm{D}^{\mathrm{bm} 13}\right.$ ) target cells (Table 3 ). These assays also showed that the $\mathrm{K}^{\mathrm{b}}$ molecule could efficiently present the $\mathrm{GP}(32-42)$ peptide because $B 10 . A(5 R)\left(K^{b} D^{\circ}\right)$ mice lysed 
Table 2. $\mathrm{H}-2^{\mathrm{bm} 13}$ does not mount an $\mathrm{H}-2 \mathrm{D}^{\mathrm{b}}$-restricted $\mathrm{GP}(32-42)$-specific cytotoxic response

\begin{tabular}{|c|c|c|c|c|c|}
\hline \multirow[t]{3}{*}{ Effectors } & \multicolumn{5}{|c|}{ Targets (\% specific release) } \\
\hline & \multicolumn{2}{|c|}{$M C 57 G\left(K^{b} D^{b}\right)$} & \multicolumn{2}{|c|}{$\mathrm{B} 10 . \mathrm{A}(5 \mathrm{H})\left(\mathrm{K}^{\mathrm{b}} \mathrm{D}^{\mathrm{d}}\right)$} & B10.HTG $\left(\mathrm{K}^{\mathrm{d}} \mathrm{D}^{\mathrm{g}}\right)$ \\
\hline & $\overline{+}$ & - & + & $\overline{-}$ & + \\
\hline C57BL/6 $\left(K^{b} D^{b}\right)$. & $\begin{array}{l}88 \\
71 \\
43 \\
23\end{array}$ & $\begin{array}{l}5 \\
5 \\
1 \\
3\end{array}$ & $\begin{array}{l}88 \\
64 \\
36 \\
17\end{array}$ & $\begin{array}{r}20 \\
13 \\
7 \\
4\end{array}$ & $\begin{array}{l}74 \\
54 \\
24 \\
13\end{array}$ \\
\hline bm13 $\left(K^{b} D^{b m 13}\right)$ & $\begin{array}{l}52 \\
41 \\
24 \\
10\end{array}$ & $\begin{array}{r}15 \\
16 \\
7 \\
4\end{array}$ & $\begin{array}{l}44 \\
42 \\
25 \\
13\end{array}$ & $\begin{array}{r}7 \\
12 \\
5 \\
0\end{array}$ & $\begin{array}{r}18 \\
21 \\
8 \\
7\end{array}$ \\
\hline
\end{tabular}

Target cells were incubated with $(+)$ or without $(-) \mathrm{GP}(32-42)$. Spontaneous release was below $25 \%$. Effector to target ratios shown are $70: 1$, $23: 1,8: 1$, and $3: 1$

$\mathrm{H}-2^{\mathrm{bm} 13}$ targets incubated with $\mathrm{GP}(32-42)$ and vice versa (4) (Tables 2 and 3). These CTL assays suggest that the presentation of $\mathrm{GP}(32-42)$ by $\mathrm{D}^{\mathrm{bm} 13}$ is very inefficient in vivo because of the lack of a measurable CTL response specific for this peptide antigen.

\section{Dlscussion}

In this study we wanted to determine whether one particular TCR was sensitive to small changes in the $\mathrm{MHC}$ with respect to positive selection, negative selection, and antigen recognition. Such studies may help to determine the interactions between the TCR and its ligand during these processes and give insights into the mechanism of signalling for the different events. The transgenic LCMV/D ${ }^{\mathrm{b}}$-specific TCR bred into $\mathrm{H}-2^{\mathrm{bm} 13}$ and $\mathrm{H}-2^{\mathrm{bm} 14}$ mice revealed the following results. The transgenic TCR cannot be positively selected in the presence of $K^{b}$ or $D^{\mathrm{bm} 14}$. $D^{\mathrm{bm} 13}$ allows positive selection of the transgenic TCR, but negative selection does not occur in the presence of LCMV. The transgenic TCR cannot recognize LCMV-infected cells expressing $D^{\mathrm{bm} 13}$, as demonstrated by the intracerebral virus challenge, proliferation, and cytotoxicity assays (Fig. 6). The lack of recognition is consistent with the interpretation that the peptide antigen p32-42 is not efficiently presented by $D^{\mathrm{bm} 13}$ and remains below a density sufficient to induce effector function or recognition in vivo.

Interestingly, positive selection of the $\mathrm{D}^{\mathrm{b}}$-restricted transgenic TCR is apparently even more efficient in the presence of the $D^{\mathrm{bm} 13}$ allele. This was demonstrated by an increased skewing to $\mathrm{CD}^{+}$mature thymocytes, an increased proportion of $\mathrm{CD} 3^{\text {hi }}$ thymocytes compared with the $\mathrm{CD} 3$ intermediate, and low subpopulations. The increased positive selection was also reflected by increased numbers of $T$ cells in peripheral blood and lymph nodes. This increase in efficiency of positive selection is not caused by new putative selecting peptides introduced from the BALB/C background, because previous work with (C57BL/6 $\times \mathrm{BALB} / \mathrm{c}) \mathrm{F}_{1}$ does not show a similar increased positive selection (23). Detailed modelling studies of the $D^{\mathrm{bm} 13}$ molecule suggest that the changes in the $\beta$-sheet of the $D^{\mathrm{bm} 13}$ molecule should not directly alter the conformation of the class I molecule and should only affect the peptide binding (33). However, subtle changes may exist and therefore it is possible that the increase in positive selection is caused directly by the shape of the $D^{\mathrm{bm} 13}$
Table 3.H-2D $\mathrm{D}^{\mathrm{bm} 13}$ does not efficiently present $\mathrm{GP}(32-42)$

\begin{tabular}{|c|c|c|c|c|}
\hline \multirow[t]{3}{*}{ Effectors } & \multicolumn{4}{|c|}{ Targets ( $\%$ specific release) } \\
\hline & \multicolumn{2}{|c|}{$M C 57 G\left(K^{b} D^{b}\right)$} & \multicolumn{2}{|c|}{$\mathrm{bm} 13\left(\mathrm{~K}^{\mathrm{b}} \mathrm{D}^{\mathrm{bm} 13}\right)$} \\
\hline & + & - & + & - \\
\hline C57BL/6 $\left(K^{b} D^{b}\right)$ & $\begin{array}{l}92 \\
86 \\
54 \\
31\end{array}$ & $\begin{array}{r}19 \\
5 \\
7 \\
1\end{array}$ & $\begin{array}{l}61 \\
75 \\
52 \\
22\end{array}$ & $\begin{array}{l}8 \\
2 \\
4 \\
5\end{array}$ \\
\hline$B 10 . A(4 R)\left(K^{k} D^{b}\right)$ & $\begin{array}{r}60 \\
34 \\
18 \\
6\end{array}$ & $\begin{array}{r}11 \\
5 \\
2 \\
2\end{array}$ & $\begin{array}{l}5 \\
5 \\
0 \\
0\end{array}$ & $\begin{array}{l}8 \\
5 \\
1 \\
4\end{array}$ \\
\hline$B 10 . A(5 R)\left(K^{b} D^{d}\right)$ & $\begin{array}{l}42 \\
43 \\
21 \\
12\end{array}$ & $\begin{array}{r}14 \\
11 \\
7 \\
4\end{array}$ & $\begin{array}{l}55 \\
49 \\
28 \\
10\end{array}$ & $\begin{array}{l}5 \\
1 \\
0 \\
0\end{array}$ \\
\hline
\end{tabular}

Target cells were incubated with $(+)$ or without $(-)$ GP(32-42). Spontaneous release was below $30 \%$. Effector to target ratios shown are $70: 1,23: 1,8: 1$, and $3: 1$.

MHC molecule itself. Alternatively, an altered conformation of the self peptide $-\mathrm{MHC}$ complex may result in an enhanced positive selection of the transgenic TCR.

Others have used similar approaches to analyse TCR - MHC interaction required for positive selection. Using a transgenic TCR specific for the male $H . Y$ antigen, presented in the context of $D^{b}$, Jacobs et al. (18) showed that the transgenic TCR could neither be selected by $\mathrm{H} \cdot 2^{\mathrm{bm} 13}$ or $\mathrm{H} \cdot 2^{\mathrm{bm} 14}$ nor could the $\mathrm{H} \cdot \mathrm{Y}$ antigen be recognized in the context of the mutant $\mathrm{H}-2$ types. A comparison with our data is interesting because both transgenic receptors are restricted to $D^{\text {b }}$, but in contrast to $H \cdot Y$ the LCMV-specific receptor is positively selected by $D^{\mathrm{bm} 13}$. This suggests that the selecting MHC complex has different requirements for different receptors. One possibility is that the conformation of a peptide presented by $D^{\mathrm{bm} 13}$ fulfills the necessary requirements for positive selection of the LCMV-specific receptor, but not the H-Y-specific receptor.

Berg et al. (19) examined positive selection of a cytochrome $c-I-E^{k}$-restricted transgenic TCR in mice expressing $I-E_{\alpha k} ; E_{g b}$. 
This transgenic TCR could weakly recognize cytochrome $c$ in the context of the hybrid I-E molecule, and correspondingly a weak positive selection of the transgenic TCR could also be demonstrated. In studies using a $\mathrm{K}^{\mathrm{b}}$-restricted transgenic TCR, Sha et al. (14) have also shown a reduction in positive selection in $\mathrm{K}^{\mathrm{bm} B}$ mice; this mutant has substitutions on the bottom of the peptide binding groove. The authors speculated that the reduced positive selection is caused by an altered selecting peptide conformation, because the TCR should not be able to directly 'see' the changes in $\mathrm{K}^{\mathrm{bma}}$. These data, together with the results from our transgenic $D^{\mathrm{bm} 13}$ and $D^{\mathrm{b}}$ animals, suggest that a gradient of binding avidities exists for thymocyte selection. At one end no selection occurs and thymocytes die. A range of affinities appears to exist that results in poor to very efficient positive selection. However, if the interaction between the TCR and the MHC ligand in the thymus is too 'strong', negative selection may occur by ctonal deletion. It is possible that the avidity of our TCR towards $D^{\mathrm{bm} 13}$ may be on the border of affinities leading to either positive and/or negative selection. The increase in mature $T$ cells in transgenic $D^{\mathrm{bm} 13}$ mice may then be a result of peripheral expansion induced by low level stimulation of the non-deleted transgenic $T$ cells.

The data presented here demonstrate that positive selection of the transgenic TCR is more 'efficient' in $D^{\text {brn13 }}$ animals compared with the original selecting element $D^{b}$. This suggests that the interaction between the TCR and MHC ligand in the thymus during positive selection is somewhat flexible and has different structural requirements than the TCR - peptide - MHC interactions required for negative selection or antigen recognition in vivo. Differences in TCR - MHC avidity may influence the ability of a given TCR to undergo positive selection and therefore may account for some of the subtle differences seen in the various TCR transgenic mouse models $(23,39)$ and nontransgenic models $(34,35)$.

\section{Acknowledgements}

We would like to thank Alana Althage for expert technical assistance with the cytotoxic assays, Luca Boliiger for help in the initial stages of this work, and Drs U. Kalinke, B. N. S. Oehen, and D. Speiser for helpful comments on the manuscript. Special thanks to $\mathrm{Dr} \mathrm{C}$. Melief for providing the bm13 and bm14 animals. P.S.O. is supported by the Medical Research Council of Canada and H.P. is supported by the Stiftung Prof. M. Cloetta. This work was funded by the Swiss National Fund, the Radiumstiftung Zurich, and Finanzpool 3R.

\section{Abbreviatlons}

$\begin{array}{ll}\text { BSS } & \text { balanced salt solution } \\ \text { Con A } & \text { concanavalin A } \\ \text { CTL } & \text { cytotoxic T lymphocyte } \\ \text { FCS } & \text { tetal calf serum } \\ \text { LCMV } & \text { lymphocytic choriomeningitis virus } \\ \text { Mls } & \text { mixed lymphocyte stimulating } \\ \text { PE } & \text { phycoerythrin } \\ \text { SEB } & \text { staphylococcal enterotoxin B }\end{array}$

\section{References}

1 Matis, L. A. 1990. The molecular basis of T-cell specificity. Arnu. Rev. Immunol. 8:65.

2 Hedrick, S. M., Matis, L. A., Hecht, T. T., Samelson, L. E., Longo, D. L., Heber-Katz, E., and Schwart, R. H. 1982. The fine hybridoma clones specific for cytochrome c. Cell 30:141.

3 Reske-Kunz, A. B. and Rüde, E. 1985. Insulin-specific T cell hybridomas derived from $(\mathrm{H}-2 \mathrm{~b} \times \mathrm{H}-2 \mathrm{k}) \mathrm{F} 1$ mice preferably employ F1-unique restriction elements for antigen recognition. Eur. J. Immunol. 15: 1048.

4 Byrne, J. A., Ahmed, R., and Oldstone, M. B. A. 1984. Biotogy of cloned cytotoxic $T$ lymphocytes specific for lymphocytic choriomeningitis virus. J. Immunol. 133:433.

5 Tevethia, S. S., Lewis, M., Tanaka, Y., Milici, J., Knowles, B., Maloy, W. L., and Anderson, R. 1990. Dissection of H-2D ${ }^{\mathrm{b}}$-restricted cytotoxic T-lymphocyte epitopes on simian virus $40 \mathrm{~T}$ antigen by the use of synthetic peptides and $H \cdot 2 D^{\text {brn }}$ mutants. J. Virol. 64:1192.

6 Ajitkumar, P., Geier, S. S., Kesari, K. V., Borriello, F., Nakagawa, M., Bluestone, J. A., Saper, M. A., Wiley, D. C., and Nathenson, S. G. 1988. Evidence that multiple residues on both the $\alpha$-helices of the class I MHC molecule are simultaneously recognized by the $T$ cell receptor. Cell 54:47.

7 Nikolic-Zugic, J. and and Carbone, F. R. 1990. The effect of mutations in the MHC class I peptide binding groove on the cytotoxic T lymphocyte recognition of the $\mathrm{K}^{\mathrm{b}}$-restricted ovalbumin determinant. Eur. J. Immunol. 20:2431.

8 Sette, A., Buus, S., Colon, S., Smith, J. A., Miles, C., and Grey, H. M. 1987. Structural characteristics of an antigen required for its interaction with la and recognition by T cells. Nature 328:395.

9 Townsend, A. and Bodmer, H. 1989. Antigen recognition of class I-restricted T lymphocytes. Annu. Rev. Immunol. 7:601.

10 Kappler, J. W., Staerz, U. D., White, J., and Marrack, P. 1988. Sell tolerance eliminates $T$ cells specific for Mls-modified products of the major histocompatibility complex. J. Immunol. 332:35.

11 MacDonald, H. R., Schneider, R., Lees, R. K., Howe, R. C.,

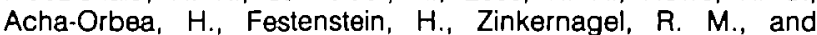
Hengartner, $H$. 1988. T cell receptor $V_{B}$ use predicts reactivity and tolerance of $\mathrm{Mls}^{\mathrm{a}}$ encoded antigens. Nature 332:40.

12 Pullen, A. M., Marrack, P., and Kappler, J. W. 1988. The T cent repertoire is heavily influenced by tolerance to polymorphic selfantigens. Nature 335:796.

13 White, J., Herman, A., Pullen, A. M., Kubo, R., Kappler, J. W., and Marrack, P. 1989. The $V_{\beta}$-specific superantigen staphylococcal enterotoxin B: stimulation of mature $T$ cells and clonal deletion in neonatal mice. Cell 56:27.

14 Sha, W. C., Netson, C. A., Newberry, R. D., Pullen, K. J., Pease, L. R., Russell, J. H., and Loh, D. Y. 1990. Positive selection of transgenic receptor-bearing thymocytes by $\mathrm{K}^{\mathrm{b}}$ antigen is altered by $\mathrm{K}^{\mathrm{b}}$ mutations that involve peptide binding. Proc. Natt Acad. Sci. USA 87:6186.

15 Pircher, H. P., Hoffmann Rohrer, U., Moskophidis, D., Zinkernagel, R. M., and Hengarther, H. 1991. Lower receptor avidity required for thymic clonal deletion than for effector $\mathrm{T}$ cell function. Nature 351:482.

16 Singer, A., Mizuochi, T., Munitz, T. I., and Gress, R. 1986. Rote of self antigens in the selection of the developing $T$ cell repertoire. In Cinader, B. and Miller, R. B., eds, Progress in Immunology VI, p. 60. Academic Press Inc., Orlando, FL.

17 Nikolic Zugic, J. and Bevan, M. J. 1990. Role of self-peptides in positively selecting the T-cell repertoire. Nature 344:65.

18 Jacobs, H., von Boehmer, H., Melief, C. J. M. and Berns, A. 1990. Mutations in the major histocompatibility complex class I antigen presenting groove affect both negative and positive selection of $T$ cells. Eur. J. Immunol. 20:2333.

19 Berg, L. J., Pullen, A. M., Fazekas de St.Groth, B., Mathis, D., Benoist, C., and Davis, M. M. 1989. Antigen/MHC-specific T cells are preferentially exported from the thymus in the presence of their MHC ligand. Cell 58:1035.

20 Morgan, G. M., Dellos, H., McKenzie, I. F. C., Metvold, R. W., and

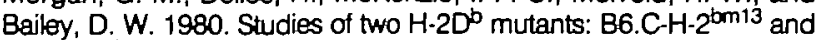
B6.C-H.2 $2^{\text {bm } 14}$. Immunogenetics 11:341.

21 Hemmi, S., Geliebter, J., Zeff, R. A., Metvold, R. W., and Nathenson, S. G. 1988. Three spontaneous $\mathrm{H}-2 \mathrm{D}^{\mathrm{b}}$ mutants are generated by genetic micro-recombination (gene conversion) events. J. Exp. Mad. 168:2319.

22 Pircher, H., Bürki, K., Lang, R., Hengartner, H., and Zinkernaget, R. 1989. Tolerance induction in double specific T-cell receptor transgenic mice varies with antigen. Nature 342:559.

23 Onashi, P. S., Pircher, H., Bürki, K., Zinkernagel, R. M., and 
Hengartner, H. 1990. Distinct sequence of negative or positive selection implied by thymocyte $\mathrm{T}$ cell receptor densities. Nature 346:861.

24 Ozato, K., Mayer, N. N., and Sachs, D. H. 1982. Monoclonal antibodies to mouse major histocompatibility complex antigens. IV A series of hybridoma clones producing anti- $\mathrm{H}-2^{\mathrm{d}}$ antibodies and an examination of expression of $\mathrm{H}-2^{d}$ antigens on the surface of these cells. Transplantation 34:113.

25 Tomonari, K. 1988. A rat antibody against a structure functionally related to the mouse T-cell receptor - T3 complex. Immunogenetics 28:455.

26 Haskins, K., Hannum, C., White, J., Roehm, N., Kubo, R., Kappler, J.W., and Marrack, P. 1984. The antigen-specific, major histocompatibility complex-restricted receptor on T cells VI. An antibody to a receptor allotype. J. Exp. Med. 160:452.

27 Pircher, H., Rebai, N., Groettrup, M., Grégoire, C., Speiser, D. E., Patt Happ, M., Palmer, E., Zinkernagel, R. M., Hengartner, H., and Malissen, B. 1992. Preferential positive selection of $\mathrm{V}_{\alpha} 2^{+} \mathrm{CD} 8^{+} \mathrm{T}$ celts in mouse strains expressing both $H \cdot 2^{k}$ and $T$ cell receptor $V_{\alpha}{ }^{a}$ haplotypes: determination with a $V_{\alpha} 2$ specific monoclonal antibody. Eur. J. Immunol. 22:399.

28 Pircher, H., Baenziger, J., Schilham, M., Sado, T., Kamisaku, H., Hengartner, H., and Zinkernagel, R. M. 1987. Characterization of virusspecific cytotoxic $T$ cell clones from allogeneic bone marrow chimeras. Eur. J. Immunol. 17:159.

29 Teh, H. S., Kisielow, P., Scott, B., Kishi, H., Uematsu, Y., Blüthmann, H., and von Boehmer, H. 1988. Thymic major histocompatibility complex antigens and the $\alpha \beta$ T cell receptor determine the CD4/CD8 phenotype of T cells. Nature 335:229.

30 Sha, W. C., Nelson, C. A., Newberry, R. D., Kranz, D. M., Russell, J. H., and Loh, D. Y. 1988. Positive and negative selection of an antigen receptor on T cells in transgenic mice. Nature 336:73.
31 Pircher, H., Hoffmann-Rohrer, U., Moskophidis, D., Zinkernaget, R. M., and Hengartner, H. 1991. Lower receptor avidity required for thymic clonal deletion then for effector $T$ cell function. Nature 351:482.

32 Crompton, T., Ohashi, P. S., Schneider, S. D., Pircher, H., and MacDonald, H.R. 1992. A cortisone sensitive CD3 $3^{\text {bow }}$ subset of $\mathrm{CD}^{+}{ }^{+} \mathrm{CD}^{-}$thymocytes represents an intermediate stage of intrathymic repertoire selection. Int. Immunol. 4:153.

33 Joyce, S., Garrett, T. P. J., Geliebter, J., Sun; R., and Nathenson, S. G. 1991. Structural correlates of MHC class I-restricted antigen-specific and allor eactive immunity. In J. McCluskey, ed., Antigen Processing and Recognition, p. 109. CRC Press Inc., Boca Raton, FL.

34 Guidos, C. J., Danska, J. S., Fathman, C. G., and Weissman, I. L. 1990. T cell receptor-mediated negative selection of autoreactive $T$ lymphocyte precursors occurs after commitment to the CD4 or CD8 lineages. J. Exp. Med. 172:835.

35 Hugo, P., Boyd, R. L., Waanders, G. A., Petrie, H. T., and Scollay, R 1990. Timing of deletion of autoreactive $V_{\beta} 6^{+}$cells and downmodulation of either CD4 or CD8 on phenotypically distinct $\mathrm{CD}_{4}^{+} 8^{+}$ subsets of thymocytes expressing intermediate or high levels of $T$ cell receptor. Int. Immunol. 3:265.

36 Hotchin, J. 1962. The biology of lymphocytic choriomeningitis infection: virus induced immune disease. Cold Spring Harbor Symp. Quant. Biol. $27: 479$.

37 Lehmann-Grube, F. 1971. Lymphocytic choriomeningitis virus. Virol. Monogr. 10:1

38 Buchmeier, M. J., Welsh, R. M., Dutko, F. J., and Oldstone, M. B. A. 1980. The virology and immunobiology of hymphocytic choriomeningitis virus infection. Adv. Immunol. 30:275.

39 Huesmann, M., Scott, B., Kisielow, P., and von Boehmer, H. 1991. Kinetics and efficacy of positive selection in the thymus of normal and T cell receptor transgenic mice. Cell 66:533. 